\title{
PENGEMBANGAN DESAIN PEMBELAJARAN INQUIRY MENINGKATKAN MOTIVASI DAN PRESTASI BELAJAR MATEMATIKA MATERI LUAS DAN VOLUME BENDA PUTAR
}

\author{
Sulistyawati \\ SMKN 1 Bendo Magetan \\ e-mail: sulistyawatibelotan@gmail.com
}

\begin{abstract}
Learning strategy which gives less chance for the students to be actively included in the learning process will reduce the interest of students in learning which resulted in the lack of students' motivation in learning which also will affect the students achievement in learning. The active learning strategy is a strategy which actively includes students to be active physically, mentally and socially. Based on these fact, the strategy of learning used by teacher plays a very important role in improving the students' motivation as well as the success of learning. To achieve the goal of learning, teacher should pay attention to: (1) reduce the direct lecture method, (2) assigns different assignment to each students, (3) groups students based on their ability, (4) the material must be modified and enriched accordingly, (5) uses variation of procedures, (6) tries to develop the learning situation based on the students' abilities, (7) motivate students to me actively engage in all learning activities. Inquiry Based Learning is an important component of constructivist approach which has a long history in innovative learning. Learning through inquiry will gives benefits for students. It spur on students' interest to know more things, motivates them to continue learning to get the final answer. Students will learn to solve problem independently and think critically as they must analyzed and arrange information.
\end{abstract}

Key Words: Inquiry Learning, Motivation, Achievement

\begin{abstract}
Abstrak: Strategi pembelajaran yang kurang melibatkan siswa akan menurunkan minat belajar siswa, sehingga motivasi belajarnya pun akan menurun dan pada akhirnya prestasi belajarnya pun tidak akan didapatkan hasil yang optimal. Strategi pembelajaran yang lebih menekankan pada aktivitas siswa merupakan metode belajar mengajar yang mengutamakan peran siswa aktif baik fisik, mental, maupun sosial. Berdasarkan pada kenyataan tersebut intinya bahwa strategi belajar yang digunakan oleh guru sangat berpengaruh terhadap motivasi belajar peserta didik, dan yang lebih penting lagi berpengaruh terhadap keberhasilan peserta didik dalam belajar. Mencapai keberhasilan peserta didik dalam belajar, maka guru perlu memperhatikan hal-hal sebagai berikut: (1) mengurangi metode ceramah, (2) memberikan tugas yang berbeda bagi setiap peserta didik, (3) mengelompokkan peserta didik sesuai dengan kemampuannya, (4) bahan harus dimodifikasi dan diperkaya, (5) gunakan prosedur yang bervariasi, (6) usahakan situasi belajar berusaha untuk mengembangkan kemampuan anak untuk bekerja sesuai dengan kemampuan, dan (7) usahakan melibatkan peserta didik dalam berbagai kegiatan. Pembelajaran dengan penemuan (inquiry) merupakan suatu komponen penting dalam pendekatan konstruktivistik yang telah memiliki sejarah panjang dalam inovasi atau pembaharuan pendidikan. Belajar dengan penemuan mempunyai beberapa keuntungan. Pembelajaran dengan inquiry memacu keinginan siswa untuk mengetahui, memotivasi mereka untuk melanjutkan pekerjaannya hingga mereka menemukan jawabannya. Siswa juga belajar memecahkan masalah secara mandiri dan memiliki keterampilan kritis karena mereka harus selalu harus menganalisis dan menangani informasi.
\end{abstract}

Kata Kunci: Pembelajaran Inquiry, Motivasi, Prestasi. 


\section{PENDAHULUAN}

Pembicaraan mengenai pendidikan selalu diarahkan kepada guru. Guru selalu dianggap sebagai pihak yang bertanggung jawab dalam operasionalisasi pendidikan ditingkat sekolah. Sehingga ketika pendidikan dituding sebagai pihak yang bertanggung jawab atas menurunnya kualitas sumber daya manusia, secara langsung guru merupakan pihak yang bertanggung jawab. Dengan demikian guru merupakan pihak yang sangat menentukan dan memegang peranan yang sangat penting terhadap kemajuan pendidikan yang bermuara pada peningkatan kualitas sumber daya manusia (Sonhadji, 1990). Berdasarkan paparan tersebut, guru memegang peranan yang sangat penting dan menentukan. Oleh karenanya, peningkatan kemampuan dan wawasan guru ini menjadi hal mutlak yang harus dilakukan agar guru dapat melaksanakan tugas dan fungsinya dengan baik.

Dalam meningkatkan kualitas sumber daya manusia Indonesia, tidak hanya menjadi tugas dan tanggung jawab para pakar, birokrat dan politisi saja, melainkan juga menjadi tugas dan tanggung jawab guru dan orang yang berkiprah di bidang pendidikan dan pengajaran. Oleh karena itu, sebagai praktisi dan pemerhati bidang pendidikan dan pengajaran, memikirkan dan mengambil langkah guna ikut berkiprah dalam meningkatkan kualitas manusia Indonesia seutuhnya, yaitu dengan meningkatkan mutu pendidikan dengan melakukan pembaharuan-pembaharuan strategi dalam pembelajaran.

Untuk meningkatkan prestasi belajar, guru harus mampu memberikan motivasi kepada peserta didik, agar dalam kegiatan belajar mengajar anak memiliki keinginan untuk mengetahui dan memahami materi yang disampaikan oleh guru. Dalam kaitan- nya dengan motivasi, guru harus mampu membangkitkan motivasi belajar peserta didik dengan memperhatikan prinsip bahwa peserta didik akan bekerja keras bila ia mempunyai minat dan perhatian terhadap materi pemhelajaran yang disampaikan oleh guru. Dengan demikian, maka kualitas peserta didik akan lebih mengarah para tujuan yang direncanakan dalam pendidikan. Pembaharuan pendidikan tersebut tidak dapat dilakukan oleh satu komponen saja, melainkan harus ada kerjasama dengan komponen lain. Lewin (1948) mengatakan bahwa pembaharuan sosial sangat tergantung pada komitmen dan pemahaman anggota masyarakat yang terlibat dalam proses perubahan itu. pendapat tersebut menunjukkan bahwa meningkatkan kualitas pendidikan itu merupakan tanggung jawab bersama antara guru, siswa, masyarakat, dan seluruh komponen pendidikan. Untuk melakukan perubahan dalam meningkatkan mutu dan kualitas pendidikan guru sangat berperan, sebab guru adalah orang kedua setelah orang tua yang bertugas sebagai pentransfer ilmu pengetahuan kepada anak. Untuk itu metode yang dilakukan guru sangat tergantung dari kreatifitas guru itu sendiri dalam menyampaikan isi materi kepada anak didik.

Fenomena-fenomena tersebut menjadikan tantangan bagi peneliti untuk dapat melakukan suatu perubahan dalam proses pembelajaran agar dapat menghasilkan suatu prestasi belajar yang optimal. Perubahan proses pembelajaran tersebut dengan menawarkan suatu strategi pembelajaran inquiry sebagai upaya meningkatkan motivasi siswa dalam belajar, yang pada akhirnya dapat meningkatkan prestasi belajar peserta didik.

Strategi pembelajaran yang kurang melibatkan siswa akan menurunkan minat belajar siswa, sehingga motivasi belajarnya pun akan menurun dan pada akhirnya prestasi belajarnya pun tidak akan didapatkan hasil 
yang optimal. Menurut Mulyasa (2002) untuk mencapai keberhasilan peserta didik dalam belajar, maka guru perlu memperhatikan hal-hal sebagai berikut: (1) mengkurangi metode ceramah, (2) memberikan tugas yang berbeda bagi setiap peserta didik, (3) mengelompokkan peserta didik sesuai dengan kemampuannya, (4) bahan harus dimodifikasi dan diperkaya, (5) gunakan prosedur yang bervariasi, (6) usahakan situasi belajar berusaha untuk mengembangkan kemampuan anak untuk bekerja sesuai dengan kemampuan, dan (7) usahakan melibatkan peserta didik dalam berbagai kegiatan.

Berdasarkan fenomena yang ada, peneliti akan melakukan penelitian tindakan kelas (action research) dengan tujuan untuk mengetahui dan mendeskripsikan bahwa dengan strategi pembelajaran inqury yang digunakan oleh guru dalam proses pembelajaran, diharapkan mampu meningkatkan motivasi belajar siswa, dan pada akhirnya dapat meningkatkan pula prestasi belajar siswa.

Penelitian ini akan mendeskripsikan suatu upaya meningkatkan motivasi belajar Penelitian Tindakan (action research) strategi pembelajaran inquiry ini dilakukan pada siswa SMKN 1 Bendo Kabupaten Magetan pada siswa kelas XII TKR 3 semester I pada mata pelajaran Matematika. Apakah dengan strategi pembelajaran inqury (menemukan) dapat meningkatkan motivasi belajar siswa kelas XII TKR 3 SMKN 1 Bendo Kabupaten Magetan dalam belajar mata pelajaran Matematika materi luas dan volume benda putar. Suatu tantangan proses pencapaian tujuan pembelajaran di SMK/ MAK di era global saat ini, untuk menghasilkan mutu pembelajaran yang optimal.

\section{METODE}

Rancangan dalam penelitian ini adalah rancangan penelitian tindakan. Menurut
Waseso (1994) penelitian tindakan merupakan proses daur ulang, mulai tahap perencanaan, pelaksanaan tindakan dan pemantauan, refleksi yang mungkin diikuti dengan perencanaan ulang.

Rancangan dalam penelitian ini direncanakan melalui beberapa tahap perencanaan, diantarannya: (1) refleksi awal, (2) peneliti merumuskan permasalahan secara operasional, (3) peneliti merumuskan hipotesis tindakan, dan (4) menetapkan dan merumuskan rancangan tindakan.

Subjek penelitian ini adalah siswa kelas XII TKR 3 SMKN 1 Bendo Kabupaten Magetan sejumlah 35 siswa.

Adapun langkah-langkah yang dilakukan oleh peneliti dalam penelitian ini adalah: 1) Observasi objek penelitian dengan tujuan untuk mengenal segala unsur lingkungan fisik dan alam sekitar khususnya kelas yang digunakan sebagai obyek penelitian; 2) Menentukan obyek penelitian. Tahap ini memastikan bahwa siswa Kelas XII TKR 3 semester I SMKN 1 Bendo Kabupaten Magetan dijadikan sebagai obyek penelitian dengan pertimbangan karakteristik yang dimiliki kelas ini sesuai dengan permasalahan yang akan di bahas oleh peneliti; 3) Pengumpulan data awal untuk pemfokusan masalah penelitian dilakukan peneliti dengan mengadakan pengamatan langsung. Hal ini dimaksudkan, agar mendapatkan data yang valid dan reliable sesuai dengan kondisi obyek penelitian. Dengan melakukan pengamatan langsung, maka peneliti akan memperoleh catatan lapangan yang dapat dipertanggungjawabkan; 4) Melakukan kegiatan pada siklus 1 yaitu proses kegiatan belajar mata pelajaran Matematika untuk siswa kelas XII TKR 3 materi luas dan volume benda putar materi luas dan volume benda putar. Obyek penelitian yaitu siswa kelas XII TKR 3 SMKN 1 Bendo Kabupaten Magetan; 5) Melakukan kegiatan pada 
siklus 2 untuk melakukan serangkaian kegiatan belajar mata pelajaran Matematika materi luas dan volume benda putar dengan menggunakan pendekatan inquiry pada siswa siswa kelas XII TKR 3 SMKN 1 Bendo Kabupaten Magetan; 6) Mengumpulkan data dari hasil pelaksanaan penelitian yang dilakukan oleh peneliti, berdasarkan pada pelaksanaan proses belajar mengajar dan hasil belajar obyek penelitian yaitu siswa kelas XII TKR 3 SMKN 1 Bendo Kabupaten Magetan; 7) Setelah data terkumpul selanjutnya mengidentifikasi, dan langkah selanjutnya adalah mendeskripsikan hasil identifikasi; 8) Mendeskripsikan dan memaparkan hasil penelitian secara kualitatif sesuai dengan fokus penelitian; 9) Peneliti membuat laporan penelitian dengan cara mendeskripsikan hasil kegiatan pembelajaran sesuai dengan judul penelitian yang dilakukan oleh peneliti.

Menurut Zuriah (2003), ada 5 jenis instrumen yang digunakan dalam penelitian tindakan. Diantaranya observasi, wawancara, catatan lapangan, angket, dan dokumentasi. Dalam penelitian ini instrumen yang digunakan meliputi:

\section{Observasi}

Observasi diartikan sebagai pengamatan dan pencatatan secara sistematik terhadap gejala yang tampak pada objek penelitian (Zuriah, 2003). Pengamatan dan pencatatan yang dilakukan terhadap objek di tempat terjadi atau berlangsungnya peristiwa.

Dalam penelitian ini metode observasi yang dilakukan oleh peneliti adalah pengamatan berperan serta. Menurut Bogdan \& Biklen (1982) ketiga teknik tersebut merupakan teknik-teknik dasar yang digunakan dalam penelitian kualitatif.

Spradley (1980) membagi tiga tahap pengamatan berperan serta dalam penelitian kualitaif, diantaranya: a) Dimulai dari peng- amatan-pengamatan yang bersifat memeriksa (descriptive observations) secara luas, dengan melukiskan situasi sosial secara umum yang ada di lokasi penelitian; b) Kemudian dilanjutkan dengan pengamatan-pengamatan yang lebih terfokus (focused observations) untuk menemukan kategori-kategori utama tentang fokus penelitian; c) Setelah itu diadakan pengamatan-pengamatan yang bersifat selektif (selective observations) untuk menemukan kategori-kategori yang lebih rinci tentang sub-sub fokus penelitian.

Tiga tahap tersebut juga dilakukan oleh peneliti dalam penelitian yang berjudul "Pengembangan Desain Pembelajaran Inquiry Meningkatkan Motivasi dan Prestasi Hasil Belajar Matematika Materi Luas Dan Volume Benda Putar Pada Siswa Kelas XII TKR 3 SMKN 1 Bendo Kabupaten Magetan".

\section{Wawancara}

Wawancara merupakan salah satu prosedur terpenting untuk mengumpulkan data dalam penelitian kualitatif, sebab banyak informasi yang diperoleh peneliti melalui wawancara. Menurut Arifin (1998) yang dimaksud dengan wawancara adalah suatu percakapan yang bertujuan memperoleh konstruksi yang terjadi sekarang tentang orang, kejadian, aktivitas, organisasi, perasaan, motivasi, pengakuan, kerisauan dan sebagainya.

Wawancara dilakukan peneliti untuk memperoleh data sesuai dengan kenyataan pada saat peneliti melakukan wawancara. Wawancara dalam penelitian ini ditujukan kepada siswa kelas XII TKR 3 SMKN 1 Bendo Kabupaten Magetan dan guru mata pelajaran Matematika di sekolah tersebut. Wawancara dalam penelitian ini menggunakan jenis wawancara mendalam yang tidak terstruktur. 


\section{Dokumentasi}

Guba \& Lincoln (1981) mengatakan bahwa dokumen dan record dapat digunakan untuk keperluan penelitian karena: (1) merupakan sumber yang stabil, kaya dan mendorong, (2) berguna sebagai bukti untuk suatu pengujian, (3) sifatnya alamiah sesuai dengan konteks, (4) hasil pengkajian akan membuka kesempatan untuk lebih memperluas pengetahuan yang diselidiki.

Moleong (1995: 103) mengemukakan, "analisis data adalah proses pengorganisasian dan pengurutan data ke dalam pola, kategori dan satuan uraian dasar, sehingga dapat, ditemukan tema seperti yang disarankan oleh data". Teknik analisis data yang digunakan dalam penelitian ini adalah analisis deskriptif. Dengan maksud bahwa penelitian deskriptif dirancang untuk memperoleh informasi tentang status gejala pada saat penelitian dilakukan. Setelah data hasil penelitian terkumpul maka, selanjutnya data tersebut disusun secara sistematis. Dengan cara diorganisir, kemudian dikerjakan yang akhirnya data tersebut diungkap permasalahan yang penting sesuai dengan topik yang sesuai dengan permasalahan.

\section{HASIL DAN PEMBAHASAN}

Kegiatan penelitian yang dilakukan selama melakukan penelitian dapat dijabarkan sebagai berikut:

\section{Siklus 1}

Pada siklus ini rencana tindakan dilakukan selama 2 jam pertemuan dengan alokasi waktu 2 x 35 menit setiap pertemuan. Dalam melaksanakan strategi pembelajaran, guru mengemukakan orientasi dan prosedur kerja siswa sebagai kegiatan pembuka. Pada kegiatan inti pelajaran, guru membagikan lembar kerja siswa sesuai dengan mata pelajaran Matematika. Yaitu materi luas dan volume benda putar. Sedangkan kegiatan penutup guru menyimpulkan hasil pembahasan dari kegiatan siswa sebagai pemantapan. Siklus 1 membahas pada mata pelajaran Matematika pada siswa kelas XII TKR 3 pada materi luas dan volume benda putar.

Tabel 1. Hasil Belajar Siswa Siklus I

\begin{tabular}{|c|c|c|}
\hline No & Nama Siswa & Hasil Belajar \\
\hline 1 & Afiandri & 60 \\
\hline 2 & Andri Tri Adiyanto & 70 \\
\hline 3 & Anik Nuryani & 70 \\
\hline 4 & Anita Iknatia & 60 \\
\hline 5 & Arif Eko Prastyo & 90 \\
\hline 6 & Arik Danang & 50 \\
\hline 7 & Dina Fitaniasari & 80 \\
\hline 8 & Duddy Susila & 60 \\
\hline 9 & Dwi Purwanto & 70 \\
\hline 10 & Eko Supriyanto & 80 \\
\hline 11 & Elita Nurul Aini & 60 \\
\hline 12 & Erna Suprihatin & 50 \\
\hline 13 & Ertika Nurma Agustin & 60 \\
\hline 14 & Fitron Ally Kafit & 80 \\
\hline 15 & Icuk Effendi & 70 \\
\hline 16 & Inka Indrawati & 50 \\
\hline 17 & Nita Nur Zhulaika & 60 \\
\hline 18 & Jefi Heri Antok & 60 \\
\hline 19 & Koko Krisyanto & 80 \\
\hline 20 & Lileng Intanly Yulia & 70 \\
\hline 21 & Lucky Diana Sari & 80 \\
\hline 22 & Makruf Ichsan & 60 \\
\hline 23 & Nike Chonia Juwita & 70 \\
\hline 24 & Niken Wulansari & 70 \\
\hline 25 & Purwanto & 60 \\
\hline 26 & Ropina & 90 \\
\hline 27 & Safitri Hartatik & 50 \\
\hline 28 & Selvian Novianto & 80 \\
\hline 29 & Slamet Riyadi & 60 \\
\hline 30 & Soni Wijianto & 70 \\
\hline 31 & Suhartini & 80 \\
\hline 32 & Uki Indriyani & 60 \\
\hline 33 & Yusep Mahardika & 50 \\
\hline 34 & Riko Aditya Iman & 60 \\
\hline 35 & Angga Dwi Handoko & 80 \\
\hline
\end{tabular}

Dari data hasil belajar tersebut dapat didistribusikan frekuensi hasil belajar siswa kelas XII TKR 3 semester I SMKN 1 Bendo Kabupaten Magetan pada siklus I sebagai berikut: 
Tabel 2. Frekuensi Hasil Belajar Siswa Siklus I

\begin{tabular}{ccccc}
\hline No & Nilai & Frekwensi & Frekwensi $\%$ & Kategori \\
\hline 1. & 100 & 0 & 0.00 & Sangat Tinggi \\
\hline 2 & 90 & 2 & 5.71 & Tinggi \\
\hline 3 & 80 & 8 & 22.86 & Cukup Tinggi \\
\hline 4 & 70 & 8 & 22.86 & Sedang \\
\hline 5 & 60 & 12 & 34.29 & Cukup \\
\hline 6 & 50 & 5 & 14.29 & Kurang \\
\hline 7 & 40 & 0 & 0.00 & Kurang Sekali \\
\hline Total & & $\mathbf{3 5}$ & $\mathbf{1 0 0}$ & \\
\hline
\end{tabular}

Hal ini menunjukkan bahwa motivasi belajar siswa kelas XII TKR 3 semester I SMKN 1 Bendo Kabupaten Magetan, dalam siklus pertama didapatkan kelompok nilai tinggi, cukup dan kurang. Untuk kategori tinggi sejumlah 28,57\% dengan rincian 5,71\% untuk nilai 90; $22,86 \%$ untuk nilai 80 . Sedangkan kategori nilai cukup sejumlah $57,15 \%$ dengan rincian $22,86 \%$ untuk nilai 70 , dan $34,29 \%$ untuk nilai 60. Sedangkan nilai kurang sejumlah $14,29 \%$, pada nilai 50 .

Peningkatan motivasi belajar siswa ini akan ditindaklanjuti pada kegiatan belajar di siklus II. Kegiatan Siklus II ini membahas kelanjutan materi yang belum dilakukan penjelasan, yaitu materi luas dan volume benda putar. Adapun rincian penjabaran dari kegiatan pada siklus II ini adalah sebagai berikut :

\section{Siklus 2}

Pada siklus ini rencana tindakan dilakukan selama 2 jam pertemuan dengan alokasi waktu 2 x 35 menit setiap pertemuan. Dalam melaksanakan strategi pembelajaran, guru mengemukakan orientasi dan prosedur kerja siswa sebagai kegiatan pembuka. Pada kegiatan inti pelajaran, guru membagikan lembar kerja siswa dengan melanjutkan materi. Sedangkan kegiatan penutup guru menyimpulkan hasil pembahasan dari kegiatan siswa sebagai pemantapan.
Siklus II membahas materi luas dan volume benda putar materinya sama dengan kegiatan pada siklus I, sehingga proses kegiatannyapun juga tidak terlalu berbeda dengan siklus I. Perbedaan yang mencolok adalah materi ulangan untuk siklus II. Berikut ini dipaparkan hasil belajar secara prosentase dari siswa Kelas XII TKR 3 semester I SMKN 1 Bendo Kabupaten Magetan dalam siklus II ini. Adapun hasilnya dapat didistribusikan dalam bentuk tabel hasil belajar sebagai berikut:

Tabel 3. Hasil Belajar Siswa Pada Siklus II

\begin{tabular}{clc}
\hline No & \multicolumn{1}{c}{ Nama Siswa } & Hasil Belajar \\
\hline 1 & Achmad Nur Rizkianto & 70 \\
\hline 2 & Adik Fima Andrian & 80 \\
\hline 3 & Agil Bagus Budi U & 80 \\
\hline 4 & Agung Budi Hartono & 70 \\
\hline 5 & Alfian Firnanda & 100 \\
\hline 6 & Alfin Satria Tri S & 70 \\
\hline 7 & Alief Putra Surdia & 90 \\
\hline 8 & Alif Ardiansyah & 80 \\
\hline 9 & Amanda Dwi Saputra & 80 \\
\hline 10 & Amirul Mu'minin & 90 \\
\hline 11 & Anasir Rozaqi & 80 \\
\hline 12 & Andri Yulianto & 70 \\
\hline 13 & Anggar Noti Arianto & 70 \\
\hline 14 & Anjun Al Hakim & 90 \\
\hline 15 & Ari Saputro & 80 \\
\hline 16 & Ary Aji Pangestu & 60 \\
\hline 17 & Ary Riyan Pangestu & 70 \\
\hline 18 & Avian Wicaksono & 70 \\
\hline 19 & Ayub Priyawa & 80 \\
\hline 20 & Bagus Dwi Subekti & 80 \\
\hline 21 & Baktiar Wisnu Prayitno & 90 \\
\hline & & \\
\hline
\end{tabular}




\begin{tabular}{clc}
\hline 22 & Bayu Aditya W P H & 70 \\
\hline 23 & Bayu Permana Putera & 80 \\
\hline 24 & Beny Ardianto & 80 \\
\hline 25 & Bima Arya Sadewa & 70 \\
\hline 26 & Danang Sujatmiko & 100 \\
\hline 27 & Danny Puji Apria & 70 \\
\hline 28 & Dayu Kurnia Bhakti & 90 \\
\hline 29 & Dede Angde Zhanindar P & 80 \\
\hline 30 & Denny Yoga Wibowo & 80 \\
\hline 31 & Deny Ade Rahmanto & 90 \\
\hline 32 & Deny Wahyu Hambali & 80 \\
\hline 33 & Dimas Fikri Aruna & 70 \\
\hline 34 & Dodik Wijatmoko & 70 \\
\hline
\end{tabular}

35 Doni Setiawan 90

Dari data hasil belajar tersebut dapat didistribusikan frekuensi hasil belajar siswa kelas XII TKR 3 semester I SMKN 1 Bendo Kabupaten Magetan, berkaitan dengan motivasi belajarnya. Kenaikan prosentase hasil belajar ini didasarkan pada hasil belajar yang dilakukan pada kegiatan siklus 1 . Adapun penjabarannya hasil kegiatan belajar pada siklus 2 adalah sebagai berikut:

Tabel 4. Frekuensi Hasil Belajar Siswa Siklus II

\begin{tabular}{ccccc}
\hline No & Nilai & Frekwensi & Frekwensi \% & $\begin{array}{c}\text { Kategori } \\
\text { Motivasi }\end{array}$ \\
\hline 1 & 100 & 2 & 5.71 & Sangat Tinggi \\
\hline 2 & 90 & 7 & 20.00 & Tinggi \\
\hline 3 & 80 & 13 & 37.14 & Cukup Tinggi \\
\hline 4 & 70 & 12 & 34.29 & Sedang \\
\hline 5 & 60 & 1 & 2.86 & Cukup \\
\hline 6 & 50 & 0 & 0.00 & Kurang \\
\hline 7 & 40 & 0 & 0.00 & Kurang Sekali \\
\hline \multicolumn{2}{c}{ Total : } & 35 & 100 & - \\
\hline
\end{tabular}

Hal ini menunjukkan bahwa motivasi belajar siswa kelas XII TKR 3 semester I SMKN 1 Bendo Kabupaten Magetan, dalam siklus kedua didapatkan kelompok nilai tinggi dan nilai cukup saja. Untuk kategori tinggi sejumlah $62,85 \%$ dengan rincian $5,71 \%$ untuk nilai $100,20,00 \%$ untuk nilai 90, dan 37,17\% untuk nilai 80 . Sedangkan kategori nilai cukup sejumlah $37,15 \%$ dengan rincian $34,29 \%$ untuk nilai 70 dan 2,86\% untuk nilai 60. Sedangkan nilai kurang tidak didapatkan dalam kegiatan belajar pada siklus ini.

Berdasar data tersebut menunjukkan bahwa antara siklus I dan siklus II motivasi belajar siswa dengan strategi pembelajaran inquiry menunjukkan peningkatan. Pada siklus I nilai tertinggi $28,57 \%$, tetapi pada pelak-sanaan siklus II peningkatan drastis dengan nilai tertinggi sejumlah $62,85 \%$, dengan jumlah responden yang sama yaitu 35 res-ponden.

Peningkatan motivasi belajar siswa ini menunjukkan bahwa prestasi belajar dipengaruhi oleh strategi belajar yang diberikan guru. Prestasi belajar dapat baik bila motivasi belajarnya juga baik.

\section{Refleksi}

Refleksi merupakan gambaran terhadap kegiatan atau pengetahuan yang baru saja diterima. Siswa mengendapkan apa yang baru dipelajarinya sebagai struktur pengetahuam yang baru, yang merupakan pengayaan atau revisi dari pengetahuan sebelumnya. Kegiatan tersebut meliputi:

\section{Analisis}

Analisis dalam penelitian pengembangan desain pembelajaran inquiry me- 
ningkatkan motivasi dan prestasi hasil belajar mata pelajaran matematika materi luas dan volume benda putar pada siswa kelas XII TKR 3 semester I SMKN 1 Bendo. (Studi pada siswa kelas XII TKR 3 semester I SMKN 1 Bendo Kabupaten Magetan) ini adalah analisis motivasi belajar yang dapat berpengaruh terhadap hasil belajar yang dilakukan oleh siswa SMKN 1 Bendo Kabupaten Magetan. Hasil belajar ini dipengaruhi oleh strategi pembelajaran yang digunakan oleh Peneliti.

\section{Sintesis}

Hal ini mengarah pada proses belajar yang dilakukan seluruh komponen belajar, baik oleh guru, sekolah, maupun siswa sebagai peserta didik.

\section{Pemaknaan}

Memaknai hasil belajar sangat diperlukan. Berdasarkan pada hasil penelitian yang dilakukan, maka jelaslah bahwa motivasi belajar sangat berpengaruh terhadap prestasi belajar. Munculnya motivsi belajar didukung oleh strategi pembelajaran yang dilakukan oleh guru.

\section{Penjelasan}

Ditegaskan dalam proses kegiatan belajar ini, diperoleh hasil belajar yang optimal dengan menggunakan strategi pembelajaran yang sesuai dengan keinginan peserta didik.

\section{Penyimpulan Data dan Informasi}

\section{Hasil}

Dari kegiatan penelitian tindakan yang dilakukan oleh peneliti, dapat disimpulkan bahwa motivasi dan prestasi hasil belajar dapat ditingkatkan dengan strategi pembelajaran yang sesuai. Motivasi yang dapat meningkatkan cara belajar peserta didik akan berpengaruh terhadap prestasi belajar yang dilakukan.
Dari pelaksanaan penelitian tindakan kelas yang dilakukan oleh peneliti menunjukkan bahwa penerapan pengembangan desain pembelajaran Inquiry dapat meningkatkan motivasi dan prestasi hasil belajar siswa kelas XII TKR 3 semester I SMKN 1 Bendo Kabupaten Magetan. Hal ini ditunjukkan oleh prestasi siswa tersebut dalam mempelajari mata pelajaran Matematika materi luas dan volume benda putar. Hasil belajar (prestasi) yang diperolah menunjukkan hasil yang sangat signifikan dengan menggunakan strategi pembelajaran inquiry. Dengan hasil belajar yang baik menunjukkan motivasi siswa kelas XII TKR 3 semester I SMKN 1 Bendo Kabupaten Magetan. Meningkat dengan pengembangan strategi pembelajaran inquiry yang digunakan oleh peneliti dalam upaya meningkatkan prestasi belajar siswa kelas XII TKR 3 SMKN 1 Bendo Kabupaten Magetan.

\section{SIMPULAN}

Berdasarkan pada hasil penelitian ini, dapat peneliti rumuskan beberapa kesimpulan, diantaranya:

1. Pengembangan Strategi pembelajaran dengan inqury dapat meningkatkan motivasi Siswa Kelas XII TKR 3 semester I SMKN 1 Bendo Kabupaten Magetan. Sebagai buktinya bahwa pengajaran yang dilakukan mengalami peningkatan yang signifikan dari hasil belajar yang diperoleh. Bahwa antara siklus I dan siklus II, motivasi belajar siswa dengan strategi pembelajaran inquiry menunjukkan peningkatan. Dari data tersebut menunjukkan bahwa antara siklus I dan siklus II, motivasi belajar siswa dengan strategi pembelajaran inquiry menunjukkan peningkatan. Pada siklus I nilai tertinggi $28.57 \%$, tetapi pada pelaksanaan siklus II peningkatan drastis dengan nilai tertinggi sejumlah $62.85 \%$, 
dengan jumlah responden yang sama yaitu 35 responden. Peningkatan motivasi belajar siswa ini menunjukkan bahwa prestasi belajar dipengaruhi oleh strategi belajar yang diberikan guru. Prestasi belajar dapat baik bila motivasi belajarnya juga baik.

2. Inquiry salah satu komponen Contextual Teaching and Learning (CTL). Strategi ini dapat dilakukan pada semua mata pelajaran.

\section{DAFTAR PUSTAKA}

Bogdan, R. C., \& Biklen, S. K. 1982. Qualitative Research In Education. Boston: Allyn \& Bacon

Guba, E. G., \& Lincoln, Y. S. 1981. Effective Evaluation. San Fransisco: losseyBass Publishers

Moleong, L. J. 1995. Metodologi Penelitian Kualitatif. Bandung: PT. Remaja Rosdakarya.
3. Strategi pembelajaran dengan menggunakan strategi pembelajaran inquiry dimungkinkan dapat meningkatkan motivasi belajar siswa kelas XII TKR 3 SMKN 1 Bendo Kabupaten Magetan pada mata pelajaran Matematika.

Spradley, J. P. 1980. Participan Observation. New York: Holt, Rinehart and Winston.

Zuriah, N. 2003. Penelitian Tindakan dalam Bidang Pendidikan dan Sosial. Edisi Pertama. Malang: Bayu Media Publishing. 